\title{
Osynliga offer: Identifiering av människohandel som hänför sig till sexuellt utnyttjande
}

\author{
Af Venla Roth ${ }^{l}$
}

\begin{abstract}
This article seeks to explain why trafficking in human beings for the purpose of sexual exploitation is so difficult to identify in Finland. Explanations are sought, for example, in the definitional uncertainties and restricted applications and interpretations of the penal provisions on human trafficking, and in their overlap with the penal provisions on pandering. Explanations are also sought in the legal history and context of prostitution, which makes violence less objectionable in the eyes of the legal system. The inability to identify prostitution-related trafficking may also be influenced by the consensus-based policy of equality, which can undermine prosecution of female-specific problems such as violence against women. The author argues that legislation must be amended and practices improved if they are to live up to legally binding international obligations. In addition, the author argues that counter-trafficking strategies and activities should be actively developed from a gender perspective so that all victims of human trafficking can be correctly identified and assisted irrespective of whether they have fallen victim to sexual or labour exploitation."
\end{abstract}

\section{Inledning}

Människohandel och därmed jämförbart utnyttjande anses utgöra en av vår tids största människorättsutmaningar. Människohandel innebär ett allvarligt brott och en kränkning av individens människovärde och integritet. Enkelt sagt är det vid människohandel fråga om grovt utnyttjande av en annan människa. Vid människohandel strävar gärningsmannen efter att få makt över offret genom att kontrollera, manipulera och hota denne, så att offret inte längre förmår skydda sig själv mot utnyttjandet eller frigöra sig från den för honom eller henne skadliga situationen. Gärningsmännen måste nödvändigtvis inte använda sig av fysiskt våld för att få sitt offer att underkasta sig utnyttjandet: diskretare psykologiska påtryck-

* Title in English: Invisible victims: Identifying trafficking in human beings for the purpose of sexual exploitation. 
nings- och tvångsmetoder räcker för att få makt över offret. Den skuld och skam som offret ofta upplever förstärker gärningsmannens grepp om offret.

I de flesta fall utnyttjas människohandelsoffren i ett ekonomiskt förtjänstsyfte. Människohandelsoffren kan utnyttjas sexuellt inom exempelvis prostitution eller annan sexindustri och -underhållning, såsom produktion av pornografi. Utnyttjandet av offren kan även vara arbetsrelaterat: offrens arbetskraft kan exploateras genom att de tvingas arbeta under dåliga arbetsvillkor och usla förhållanden. Även arbetsrelaterat utnyttjande kan innehålla sexuellt utnyttjande och våld. Människohandel kan även bestå av organ- eller vävnadshandel i ekonomiskt förtjänstsyfte, tvångsäktenskap eller försäljning och uppköp av barn i adoptionssyfte. Även tiggeri kan ha anknytningar till människohandel. Människohandelsoffren utgörs av kvinnor, män och barn under 18 år. Inom Europa beräknas $10 \%$ av människohandelsoffren vara barn. ${ }^{2}$

Människohandel kan vara antingen internationell gränsöverskridande eller statsintern brottslighet, och den kan hänföra sig till illegal immigration, människosmuggling eller olaglig vistelse i landet. Merparten av människohandelsoffren som identifierats i Finland har även varit utlänningar som vistats temporärt i landet, eller personer som redan tidigare fallit offer för människohandel i något annat EU-medlemsland då de sökt asyl där. Ofta har de identifierade människohandelsoffren haft uppehålls- och arbetstillstånd i landet. I de flesta europeiska länder har man först nyligen börjat bli varse att även landets egna medborgare kan falla offer för människohandel. Även i Finland har man redan identifierat flera människohandelsoffer med finsk bakgrund, som utnyttjats sexuellt antingen i Finland eller utomlands. Människohandel kan ha anknytningar till organiserad brottslighet. Utöver organiserade kriminella sammanslutningar kan dock även offrens anhöriga, bekanta, släktingar, vänner, pojkvänner, makar och helt vanliga arbetsgivare, som inte har några kontakter till organiserade kriminella sammanslutningar göra sig skyldiga till människohandel. ${ }^{3}$ Även i Finland har observerats att människohandel inte nödvändigtvis hänför sig till organiserad brottslighet, utan att offren och gärningsmännen ofta har känt eller åtminstone känt till varandra sedan tidigare.

Även i bästa fall kan enbart otillförlitliga och overifierade uppskattningar ges av människohandelsoffrens världsomfattande antal. Myndighetskällors och organisationers uppskattningar om människohandeln varierar årligen mellan en halv miljon och fyra miljoner människohandelsoffer. Även i Europa beräknas offrens antal stiga till hundratals tusen varje år. Betydligt färre människohandelsoffer identifieras emellertid. Även brottmål som berör människohandel behandlas förhållandevis sällan i domstolarna. ${ }^{4}$ 
Även Finland uppskattas vara ett transit- och destinationsland för hundratals människohandelsoffer årligen, men hittills har enbart drygt hundra offer identifierats, och sammanlagt har enbart fem fall behandlas i domstolarna. Detta väcker frågan om huruvida offrens antal beräknas fel eller huruvida man inte förmår identifiera människohandel. Bägge förklaringsmodeller är möjliga. Internationella erfarenheter visar dock att den effektivaste verksamheten mot människohandel finns på ställen där både lagstiftning och myndighetspraxis gynnar identifieringen av människohandelsoffer och vägledningen för hur de kan söka hjälp (t.ex. Nederländerna, Belgien och Italien).

Människohandel är ett könsrelaterat fenomen. Enligt uppskattningar blir kvinnor och flickor oftare än män och pojkar offer för både sexuellt och arbetsrelaterat utnyttjande. Åtminstone i Europa anses sexuellt utnyttjande av kvinnor och flickor vara den typiska formen av människohandel, men även vid människohandel i form av arbetsrelaterat utnyttjande utgörs de flesta offren av kvinnor eller flickor. ${ }^{5}$ Då man i början 2000-talet gjorde upp den första verksamhetsplanen mot människohandel i Finland, föreställde man sig att människohandeln även i Finland primärt hänförde sig till prostitution och annat sexuellt utnyttjande. ${ }^{6}$ Något överraskande har människohandel som hänför sig till prostitution och sexuellt utnyttjande i Finland hittills identifierats i betydligt lägre mån än arbetsrelaterad människohandel och därtill anknutet utnyttjande av arbetskraft. Ungefär tre fjärdedelar av offren som vägletts till det hjälpsystem för människohandelsoffer som inofficiellt inledde sin verksamhet år 2005, har i första hand blivit offer för arbetsrelaterat utnyttjande, och även en stor del av de personer som utnyttjats sexuellt har blivit offer för människohandel i något annat EU-medlemsland före de sökt sig till Finland (mera om hjälpsystemet nedan). Koppleribrott innehållande drag av människohandel kommer till polisens kännedom, men eljest identifieras människohandel eller annat våld marginellt inom prostitutionen.

Målet med denna artikel är att utreda varför det är så svårt att identifiera människohandel som hänför sig till sexuellt utnyttjande. Inledningsvis presenteras definitionen på människohandel i internationell rätt och dess förhållande till prostitution diskuteras. Därefter behandlas människohandeln i Finland, identifieringen av människohandel i straffprocessen samt människohandelsoffrens särställning och förverkligandet av deras rättigheter. Slutligen reflekteras närmare över de orsaker som kunde förklara det låga antalet offer för sexuellt utnyttjande vid människohandel. I artikeln hävdas, att svårigheten i att identifiera dessa offer kan förklaras med orsaker som har att göra med bl.a. definitionen på människohandel och rättshistoria. 


\section{Definitionen på människohandel $\mathrm{i}$ internationell rätt och dess förhållande till prostitution}

Människohandel, denna moderna form av slaveri, är inte ny varken som fenomen eller rättsligt regleringsobjekt. Internationellt sett har slavhandel och slaveri motarbetats sedan 1800-talet. Till exempel Förenta nationernas konvention från år 1949 om bekämpning av människohandel och utnyttjande av prostituerade förpliktar konventionsstaterna att förbjuda handel med kvinnor, koppleri och bordellverksamhet. Konventionen innehåller däremot inte en definition på människohandel. Människo- eller kvinnohandel definieras inte heller i de internationella konventionerna om bekämpning av s.k. vit slavhandel, genom vilka man i huvudsak strävade till att bekämpa europeiska kvinnors prostitution i kolonierna. ${ }^{7}$

Sovjetunionens fall och de väpnade konflikterna i det forna Jugoslavien i skiftet av 1980- och 1990-talet återförde på nytt människohandeln till det internationella samfundets agenda efter åtskilliga års paus. I huvudsak berodde detta på den tydligt ökande migrationen inom Europa och de organiserade kriminella sammanslutningar som förmodades verka i bakgrunden för denna, och som man fruktade att skulle hota den allmänna ordningen och säkerheten i staterna. Hotet från den gränsöverskridande brottsligheten intensifierade samarbetet inom det internationella samfundet. Det ansågs inte längre vara nog med att godta internationella konventioner för att bekämpa organiserad brottslighet och därtill anknuten människohandel och människosmuggling. Efter flera års diskussioner godkändes FN:s konvention mot gränsöverskridande organiserad brottslighet i december 2000 (FördrS 20/2004). Syftet med konventionen är att främja samarbete för att på ett mer effektivt sätt förebygga och bekämpa gränsöverskridande organiserad brottslighet (art. 1). Till konventionen hänför sig även tilläggsprotokollet om förebyggande, bekämpande och bestraffande av handel med människor, särskilt kvinnor och barn (FN:s tilläggsprotokoll mot människohandel, FördrS 71/2006). ${ }^{8}$ Syftet med tilläggsprotokollet mot människohandel är att förebygga och bekämpa människohandel, skydda och bistå offren för människohandel samt främja samarbetet mellan parterna för att uppnå dessa syften (art. 2). Tilläggsprotokollet mot människohandel innehåller den första internationellt erkända definitionen på människohandel, och det förpliktar till straffbeläggning av människohandel i enlighet med den definition som nämns i protokollet (art. 3 och 5). Tilläggsprotokollet mot människohandel tillämpas på förebyggande, utredning, lagföring och skydd för offer av människohandel när människohandelsbrottet är gränsöverskridande till sin natur och en organiserad brottslig sammanslutning är delaktig (art. $4)$. 


\section{Venla Roth}

Överenskommelsen om definitionen på människohandel är det viktigaste resultatet av avtalsdiskussionerna om FN:s tilläggsprotokoll mot människohandel. Definitionen främjar förebyggandet och identifieringen av människohandel, bistående av och skydd för offer samt förverkligandet av straffansvaret för personer som gjort sig skyldiga till människohandel. ${ }^{9}$ Den godtagna definitionen på människohandel beaktar att såväl kvinnor, barn som män kan utgöra offer för människohandel, och den innefattar alla syftemål med människohandel. Definitionen i FN:s tilläggsprotokoll mot människohandel har senare godkänts som basis för åtskilliga internationella och regionala rättsakter mot människohandel. För att det skall vara fråga om uttryckligen människohandel vid sådan brottslig verksamhet som avses i tilläggsprotokollet, och inte t.ex. koppleri, människosmuggling eller lindrigare utnyttjandebrott inom arbetslivet, skall definitionen på människohandel uppfyllas. Tilläggsprotokollet mot människohandel definierar människohandel utgående från tre grundelement: verksamhet, medel och syfte. Samtliga dessa delfaktorer skall samtidigt uppfyllas för att det skall vara fråga om människohandel. Enligt FN:s tilläggsprotokoll mot människohandel innebär människohandel:

1) rekrytering, transport, överföring, hysande eller mottagande av personer i syfte att utnyttja dem (verksamhet/handlingssätt)

2) genom hot eller bruk av våld eller andra former av tvång, bortförande, bedrägeri vilseledande, maktmissbruk eller missbruk av en persons utsatta belägenhet eller givande eller mottagande av betalning eller förmåner för att erhålla samtycke från en person som har kontroll över en annan person i syfte att utnyttja denna person (medel).

3) Utnyttjande skall innebära åtminstone utnyttjande av andras prostitution eller andra former av sexuellt utnyttjande, tvångsarbete eller tvångstjänst, slaveri eller med slaveri jämförbara bruk eller sedvänjor, träldom, utnyttjande av verksamhet i samband med tiggeri eller av olaglig verksamhet, eller avlägsnande av organ (syfte).

4) Såvida något av den nämnda medlen har använts för att erhålla offrets samtycke, saknar samtycket betydelse. Rekrytering, transport, överföring, hysande eller mottagande av barn i syfte att utnyttja dem anses alltid utgöra människohandel, trots att nämnda medel inte skulle ha använts. Med barn avses en person under 18 års ålder.

Det var inte någon lätt uppgift att komma överens om definitionen. De största meningsskiljaktigheterna rörde förhållandet mellan människohandel och prostitution. Avtalsförhandlarna uppdelade sig grovt sett i två huvudgrupper: abolition- 
ister och liberalister (som krävde att prostitution skulle legaliseras). Abolitionisterna försvarade den ståndpunkt som godkändes i FN:s människohandelskonvention från år 1949, enligt vilken all prostitution skall fördömas, utan något särskiljande mellan människohandel eller tvångsprostitution eller annan prostitution. Enkelt sett betraktar abolitionisterna all prostitution som våld och slaveri, vilket inte står i samklang med människovärdet. Enligt dem skall kvinnor skyddas mot allt utnyttjande, och ett samhälle som godtar eller tillåter prostitution kan inte vara jämlikt.

Enligt liberalisterna existerar frivilig prostitution och sexarbete, som skall särskiljas från påtvingad prostitution och människohandel. De anser att frivillig prostitution som utövas av vuxna kvinnor och män inte kan förbjudas. Enligt liberalisterna kränker prostitution som sådan inte människovärdet, och individernas fria viljeyttring skall respekteras. De är övertygade om att den skam som orsakas av prostitution och därigenom samhälleligt marginaliserar de prostituerade skulle minska om prostitution skulle definieras som ett arbete. Liberalisterna menar att legaliseringen av prostitution och erkännandet av att prostitution utgör ett arbete skulle skydda de prostituerade mot våld och utnyttjande i större mån än den abolitionistiska synen. Motsvarande diskussion om prostitution har även förts inom vetenskapen. ${ }^{10}$

Den definition på människohandel som ficks till stånd under avtalsförhandlingarna om FN:s tilläggsprotokoll mot människohandel är en kompromiss. I ett rättsligt hänseende tar FN:s tilläggsprotokoll mot människohandel inte i sig ställning till den nationella regleringen av koppleri eller prostitution. Enligt tilläggsprotokollets officiella tolkningsanvisningar (Interpretative Notes) gäller protokollet utnyttjande i prostitutionssyfte och annat sexuellt utnyttjande enbart i samband med reglering av människohandel. ${ }^{11}$ Utnyttjande i prostitutionssyfte och annat sexuellt utnyttjande definieras inte i tilläggsprotokollet, så enligt tolkningsanvisningarna inverkar protokollet inte på avtalsstaternas nationella lagreglering av prostitution. De prostitutionspolitiska avgörandena påverkas emellertid av tilläggsprotokollets annotation, som förpliktar avtalsstaterna att vidta lagstiftningsoch andra åtgärder för att motverka sådan efterfrågan som främjar alla former av utnyttjande av människor, särskilt kvinnor och barn, som leder till handel med människor (art. 9). Europarådets konvention om bekämpande av människohandel, som godkändes år 2005, förpliktar avtalsstaterna att överväga att kriminalisera användningen av tjänster som är föremål för människohandel (art. 19). ${ }^{12}$

Diskussionen om människohandel och dess förhållande till prostitution pågår på den nationella nivån i alla de sammanhang där potentiella människohandelsoffer påträffas, till exempel vid identifieringen av människohandelsoffer och väg- 
ledningen av dem till hjälpsystem eller inom straffprocessen. Frågan lyder: Vad är egentligen människohandel och vem utgör ett offer för människohandeln? Ur en rättslig synvinkel lämnar definitionen på människohandel i FN:s tilläggsprotokoll mot människohandel rum för tolkning vad gäller dess förhållande till prostitution, och orsakar svårigheter för lagtillämparen. Klart är nog att all prostitution inte utgör människohandel. Men när är det sexuella utnyttjandet inom prostitutionen så allvarligt att det uppfyller rekvisitet/definitionen på människohandel?

Vid tolkningen av definitionen på människohandel skall uppmärksamhet för det första fästas vid att offrets samtycke till utnyttjandet saknar relevans såvida något av de medel som nämns i definitionen har använts vid utnyttjandet. Sålunda kan det vara fråga om människohandel även i sådana fall då gärningsmannen genom brukat av sådana i definitionen nämnda otillbörliga medel har fătt offret att prostituera sig, trots att denne ursprungligen samtyckt till prostitutionen. $\AA$ andra sidan utvidgas definitionen på människohandel av de i definitionen nämnda medlen. Definitionen på människohandel utsträcker sig vad avser medel utöver våldsamt tvingande och vilseledande till prostitution även till maktmissbruk eller missbruk av offrets utsatta belägenhet. Enligt tolkningsanvisningarna till tilläggsprotokollet är det emellertid fråga om missbruk av utsatt belägenhet enbart då personen inte haft andra reella eller godtagbara möjligheter än att underkasta sig utnyttjandet.

Tillämpningen och tolkningen av medlen gällande maktmissbruk och missbruk av utsatta personers belägenhet har i många EU-länders straffprocesser visat sig utmanande: När är en person i en sådan belägenhet och såpass beroende av gärningsmannen att personen inte haft möjlighet att agera annorlunda, och när måste gärningsmannen ha insett detta (uppsåtskrav), särskilt om offret ursprungligen har gått med på prostitutionen och gärningsmannen småningom har bemäktigat sig offret? Med tanke på definitionens tolkning är vissa stereotypiska - om än ovanliga - situationer enkla. Detta är t.ex. fallet då människohandelsoffret har förts in i prostitutionen genom våld eller offret vilseletts i fråga om arbetets natur därigenom, att offret inbillat sig få arbeta som exempelvis modell, servitris eller hembiträde, men gärningsmännen i själva verket tvingat offret att prostituera sig genom våld eller frihetsberövande.

\section{Identifiering av våld inom prostitutionen: ideala offer, osynliga kedjor}

\subsection{Rekvisitet för människohandel}

Även i Finland förändrades prostitutions- och kopplerifältet av Sovjetunionens fall. Koppleriet med utländska kvinnor blev mer internationellt, organiserat och professionellt än tidigare, och allt större ekonomiska vinningar eftersträvades vid 
verksamheten. ${ }^{13}$ Enligt forskare och polisen hade hallickarna börjat använda sig av olika slags påtrycknings- och tvångsmedel, genom vilka de strävade till att begränsa de prostituerades rörelsefrihet och förhindra att de frigjorde sig från prostitutionen. De prostituerades ställning inom koppleriverksamheten hade märkbart försvagats: de prostituerade blev tvungna att överlåta en allt större andel av sina inkomster till hallickarna och deras förhandlingsmöjligheter om reglerna och omständigheterna för prostitutionen hade minskat. Kontrollen av de prostituerade underlättades av telefonoperatörsverksamheten, som på samma gång möjliggjorde att koppleriverksamheten kunde ledas från utlandet samt utvidgas runtom $\mathrm{i}$ landet. De dåvarande legislativa lösningarna i utlänningslagen och ordningslagen försvagade å sin sida framför allt ställningen för de utländska prostituerade och orsakade att hallickarnas grepp ytterligare stramades åt. Dessa lagstiftningsändringar återkommer vi till senare $\mathrm{i}$ artikeln.

Trots förändringarna inom prostitutions- och kopplerifältet trodde man länge att Finland inte berörs av människohandeln. De utländska prostituerade som anlände till Finland ansågs vara »helt på det klara med sitt arbetes natur och villkor«: Utländska kvinnor smugglades inte till Finland »mot deras vilja«, utan det var snarare fråga om koppleri som både de prostituerade själva och deras hallickar drog nytta av. ${ }^{14}$ Möjligheterna att ingripa i det organiserade kopplerifenomenet genom strafflagen ifrågasattes emellertid, och i vissa undersökningar rekommenderades att man skulle föreskriva en särskild bestämmelse om människohandel i strafflagen. ${ }^{15}$ Ratificeringen av FN:s tilläggsprotokoll mot människohandel och godkännandet av EU:s rambeslut om människohandel ledde slutligen till att man inom justitieministeriet började förbereda bestämmelser om människohandel och andra nödvändiga lagstiftningsändringar för att effektivera verksamheten mot prostitution, koppleri och människohandel. ${ }^{16}$ Utöver bestämmelserna om människohandel tillade man även rekvisitet grovt koppleri till strafflagen, vilket gav förundersökningsmyndigheterna omfattande möjligheter att använda sig av tvångsmedel vid undersökningen av koppleribrott. I oktober 2006 tillkom dessutom en lag som förbjuder utnyttjandet av personer som är föremål för sexhandel. Det är inte fråga om en lag som förbjuder allt köp av sex; i lagen fastställs att föremål för sexhandel enbart utgörs av personer som är föremål för koppleri eller offer för människohandel (20 kapitlet $8 \S$ i strafflagen). Enligt 25 kapitlet $3 \S$ i Finlands strafflag skall den dömas för människohandel som genom att

1) utnyttja någon annans beroende ställning eller skyddslösa läge,

2) vilseleda någon annan eller genom att utnyttja att någon vilseletts,

3) betala ersättning till en person som har kontroll över en annan person, eller 
4) ta emot en sådan ersättning

tar kontroll över någon eller rekryterar, överlåter, transporterar, tar emot eller inhyser någon i syfte att göra honom eller henne till föremål för sexuellt utnyttjande enligt 20 kap. $9 \S 1$ mom. 1 punkten eller därmed jämförbart sexuellt utnyttjande, tvångsarbete eller andra förhållanden som kränker människovärdet eller i syfte att avlägsna organ eller vävnader i ekonomiskt vinningssyfte.

Enligt 25 kapitlet 3 a § i strafflagen skall för grov människohandel dömas om vid människohandel 1) våld, hot eller list används i stället för eller utöver de medel som avses i $3 \S, 2$ ) någon uppsåtligen eller genom grov oaktsamhet tillfogas svår kroppsskada eller allvarlig sjukdom, försätts i livshotande läge eller utsätts för därmed jämförbart synnerligen kännbart lidande, 3) brottet riktar sig mot ett barn under aderton år eller mot en person som har en väsentligt nedsatt förmåga att försvara sig, eller 4) brottet har begåtts som ett led i en i 17 kap. 1 a $§ 4$ mom. avsedd organiserad kriminell sammanslutnings verksamhet, och gärningen även bedömd som en helhet är grov. För grundformen av människohandel skall dömas till fängelse i minst fyra månader och högst sex år och för grov människohandel till fängelse i minst två och högst tio år. Friheten utgör det primära skyddsobjektet för straffbestämmelserna om människohandel.

\subsection{Människohandel och koppleri i rättspraxis}

Straffbestämmelserna om människohandel har enbart i ett fătal fall tillämpats i Finland. Tillsvidare har enbart fem fall av människohandel behandlats i domstolarna. Tre av dem har gällt sexuellt och två arbetsrelaterat utnyttjande. Bägge åtal för arbetsrelaterad människohandel har förkastats i domstolarna. Åtalen för sexuellt utnyttjande har bifallits åtminstone delvis. Fallen påvisar hur utmanande det är att i praktiken tillämpa och tolka definitionen på människohandel, såvida det inte är fråga om ett väldigt uppenbart, stereotypiskt och idealt människohandelsoffer, som har förts in i prostitution genom antingen bruk av fysiskt våld, vilseledande om arbetets natur eller utnyttjande av offrets förståndshandikapp. Ytterligare verkar det som en stor del av de fall som innehåller antydningar om människohandel undersöks och åtalas som ett närliggande brott, dvs. koppleri.

I juli 2006 gav Helsingfors tingsrätt den första domen för människohandel i Finlands historia. I fallet åtalades åtta personer för grov människohandel och sekundärt för grovt koppleri. Svarandena som åtalades för människohandel hade värvat kvinnor från Estland till prostitution, transporterat kvinnorna till Finland och inkvarterat dem i lägenheter och hotellrum de arrangerat i olika städer. Kun- 
derna kände till hur de skulle ta kontakt med kvinnorna per telefon på basis av de annonser svarandena lagt ut på Internet. Svarandena hade själva lagt beslag på största delen av de medel som kvinnorna införskaffat genom prostitutionen. Enligt åklagarens syn hade svarandena vilselett två av kvinnorna att prostituera sig genom att lova den ena av dem eskortservicearbete och den andra arbete med barnskötsel. Ytterligare ansåg åklagaren att svarandena hade övervakat, begränsat, hindrat och bestämt över kvinnornas rörelse och därigenom tagit kvinnorna i sitt våld. Åklagaren ansåg att gärningarna var grova eftersom kvinnorna hade hotats med våld.

Tingsrätten ansåg att de sex svarandena gjort sig skyldiga till grov människohandel och grovt koppleri. Tingsrätten ansåg att verksamheten utgjorde människohandel enbart till den delen som den hade riktat sig mot en ung utvecklingsstörd kvinna som vilseletts angående arbetets natur. Ifrågavarande kvinna trodde att hon var på väg till Finland för att arbeta med barn. Ifråga om de tretton andra kvinnorna som fungerat som prostituerade ansåg tingsrätten att svarandena gjort sig skyldiga till enbart grovt koppleri. I rätten berättade flera av dessa kvinnor om begränsning av deras rörelsefrihet, ekonomiska sanktioner och hot om våld. Tingsrätten ansåg att kvinnornas berättelser om hoten som riktats mot dem i sig var trovärdiga, men ansåg att hoten om våld enbart för den förståndshandikappade kvinnans del skapat ett sådant skyddslöst läge som avses i förarbetena till människohandelsbestämmelserna.

Tingsrätten ansåg det visat att det hade uppställts arbetstider för kvinnorna, att deras rätt att röra sig utomhus hade begränsats och att det hade »uppställts målsättningar« för deras arbete. Efterföljandet av dessa regler hade övervakats och det hade utsatts böter för brott mot dem. Trots att domstolen medgav att även dessa kvinnor varit $\mathrm{i}$ en svag ställning, ansåg den inte dem ha varit såpass utsatta $\mathrm{i}$ förhållande till svarandena, att den skulle ha ansett att deras självbestämmanderätt skulle ha kränkts på det sätt som avses i rekvisitet för människohandel. Domstolen ansåg det bl.a. vara betydelsefullt att målsägandena frivilligt hade gett sig in i prostitutionen eller åtminstone förstått att de skulle bli tvungna att erbjuda »intimtjänster« då de begav sig till Finland och att de hade tjänat pengar genom prostitutionen. Straffrättsligt handlar koppleri om att skaffa sig ekonomisk vinning genom en annan persons prostitution, genom att t.ex. ordna ett rum eller något annat ställe för idkande av prostitution, förmedla den prostituerades kontaktuppgifter eller på annat sätt utnyttja en annan persons prostitution. Vid förundersökningen fästs särskild uppmärksamhet vid frågan om huruvida svaranden kände till att prostitution idkades i de utrymmen denne ordnat eller uthyrt. 
För en kvinnas del ansåg domstolen att det inte var trovärdigt att hon pressats att fortsätta med prostitutionen, eftersom det inte visats att hon var rädd för hotelserna. Rätten ansåg det inte heller trovärdigt att den ifrågavarande kvinnans liv avsevärt hade begränsats. Detta motiverade tingsrätten med att kvinnan hade sällskapat, och fortfarande var villig att sällskapa, med en av svarandena. Tingsrätten ansåg inte kvinnans påstående om att hon inte tillåtits sluta med prostitutionen om hon så ville vara trovärdigt. Denna uppfattning baserade tingsrätten på det faktum att kvinnan åtskilliga gånger begett sig till Estland och gång på gång återvänt till prostitutionen i Finland. Domstolen förkastade även kvinnans skadeståndsyrkande på den grunden att hon inte längre hade ställning som målsägande i saken efter att åtalet om människohandel förkastats. Som vittne till koppleribrottet ansåg domstolen att hon inte var berättigad till brottsbaserad ersättning.

I det andra människohandelsfallet som hänförde sig till sexuellt utnyttjande dömdes tre finska män och två kvinnor för grov människohandel till ovillkorliga fängelsestraff, då dessa hade utsatt en ung finsk kvinna för sexuellt utnyttjande eller andra omständigheter som kränkte hennes människovärde under sommaren 2008. I bakgrunden för händelserna fanns en fingerad tjallarskuld som svarandena hade tvingat målsäganden att betala åt dem genom att bland annat sälja sexuella tjänster. Ytterligare hade svarandena tvingat målsäganden att ge dem hennes besparingar, ta snabblån, beställa varor från webbaffärer och öppna Internet- och telefonanslutningar. Svarandena hade beslagtagit målsägandens personliga egendom; bland annat hennes hemnycklar, bussbiljett och telefon. Målsägandens rörelse övervakades, hon fängslades i en källare, hon hotades till livet, hon utsattes upprepade gånger för våld och slutligen tvingades hon sälja sexuell tjänster för att införskaffa pengar. Tingsrätten ansåg att svarandena genom begränsandet av rörelsefriheten, skuldförhållandet, våldshoten och våldet bundit målsäganden till en sådan ställning där hon inte hade andra val än att underkasta sig utnyttjandet. Domstolen ansåg att målsäganden under våldshoten hade strävat till att minimera sannolikheten för att skadas genom att göra sådana val som inte hade baserat sig på frivillighet och fri viljebildning. Målsäganden hade inte vågat rymma eller vägra sälja sex. Hovrätten ändrade till väsentliga delar inte tingsrättens avgörande.

I det tredje människohandelsfallet som hänförde sig till sexuellt utnyttjande var det återigen fråga om införandet av en ung estnisk utvecklingsstörd kvinna till Finland för prostitution. Svarandena hade försatt målsäganden i en svag ekonomisk situation genom att för sina egna behov ta snabblån i målsägandens namn. Svarandena hade lockat målsäganden till Finland. Då det framgick för målsäganden att hon skulle tjäna pengar genom prostitution vågade hon inte längre säga 
nej. Målsäganden fruktade att svarandena skulle lämna henne ensam och medellös i Finland. Hon kunde inte det finska språket och kände ingen i Finland. Svarandena hade lockat målsäganden att fortsätta prostitutionen genom att berätta åt henne att det fanns möjligheter att åka till Sverige och arbeta. Som villkor för detta var att målsäganden först måste tjäna tillräckligt med pengar genom prostitutionen. Den ena svaranden hade tidigare sällskapat med målsäganden. Målsäganden och svarandena hade sinsemellan delat på pengarna som införtjänats genom prostitutionen. Efter två veckors vistelse i Finland hade svarandena lämnat Finland utan att berätta åt målsäganden. Målsäganden hade ängsligt fortsatt att sälja sexuella tjänster, tills polisen fann henne i ett mentalt dåligt skick i ett hotellrum.

Tingsrätten ansåg att svarandena enbart hade gjort sig skyldiga till koppleri. Enligt domstolen hade svarandena inte begränsat målsägandens rörelsefrihet och målsäganden hade inte varit tvungen att gå med på alla svarandenas krav. Domstolen ansåg att målsäganden hade haft tillräcklig intellektuell kapacitet att agera annorlunda. Tingsrätten lade i sitt avgörande en avsevärd betydelse vid huruvida målsäganden hade förstått att syftet med resan var att sälja sexuella tjänster i Finland.

Åklagaren överklagade avgörandet till hovrätten, som dömde svarandena för människohandel. I sitt avgörande lade hovrätten betydelse vid målsägandens beroendeställning och skyddslösa tillstånd, och ansåg att målsäganden till följd av sina bristfälliga språkkunskaper och skyddsnät, skuldsättning och därav orsakade svaga ekonomiska situation samt psykiska egenskaper var så resurslös att hon inte hade haft andra reella eller beaktansvärda alternativ än att foga sig vid att fortsätta sälja sexuella tjänster, även efter att svarandena redan lämnat landet. Hovrätten konstaterade vidare att svarandena måste ha insett att målsäganden var särskilt mottaglig för utnyttjande, och att de således handlat uppsåtligen. Hovrätten lade betydelse vid bland annat det faktum att målsäganden var lättledd och styrd, att målsäganden inte hade nödvändiga språkkunskaper och inte upplevde sig kunna återvända till Estland efter att hennes släktingar fått veta om prostitutionen, och att hon påtvingad av omständigheterna hade fortsatt prostitutionen ännu efter att svarandena lämnat Finland. Slutligen hade målsäganden varit $\mathrm{i}$ ett sådant mentals tillstånd, att hon inte på eget initiativ hade varit kapabel att frigöra sig från prostitutionen. Fallet visar hur olika domstolar kan bedöma människohandel.

Hovrättens tolkning motsvarar den internationella definitionen på människohandel och ligger i bättre linje med vad man borde sträva till att skydda med kriminaliseringen av människohandel: frihet, sexuell självbestämmanderätt och 
kroppslig integritet. Dessvärre har denna tolkning ännu inte spridit sig till förundersökningsmyndigheterna eller åklagarväsendet, där en tämligen stereotypisk bild av människohandel fortfarande verkar råda.

Minoritetsombudsmannen, som fungerar som nationell människohandelsrapportör, överlämnade i juni 2010 sin första människohandelsrapport till riksdagen. ${ }^{17}$ Rapporten baserar sig på kopplerimål som behandlats i domstolarna åren 2004-2009. Materialet omfattar såväl domstolsavgöranden som förundersökningsprotokoll. Ur människohandelsrapporten framgår att det inte är ovanligt med rättskränkningar som riktas mot utländska prostituerade av hallickar, och att de prostituerade kontrolleras på flera olika sätt. Hallickarna försätter de prostituerade i skuldförhållanden genom att indriva ansenliga hyreskostnader eller annons, dags- och veckoavgifter oberoende av om den prostituerade haft några kunder. Genom skuldförhållandet förmår hallickarna de prostituerade att fortsätta prostitutionen, även då dessa skulle vilja lägga av med den. Hallickarna kan dessutom uppställa ensidiga »arbetstider« för de prostituerade samt bestämma prisen på tjänsterna. De kontrollerar de prostituerades rörelse och verksamhet per telefon eller med hjälp av telefonoperatörer. Hallickarna kan lägga beslag på de prostituerades resedokument, och ibland bränner hallickarna dokumenten för att garantera att de prostituerade inte lämnar landet före de betalat tillbaka sin skuld åt hallickarna. Därtill hotar hallickarna de prostituerade och deras familjemedlemmar med fysiskt och sexuellt våld.

Enligt rapporten anses dessa mot individen riktade rättskränkningar emellertid inte uppfylla de i straffbestämmelsen om människohandel nämnda medlen, såsom exempelvis utnyttjande av någon annans beroende ställning eller skyddslösa läge, vilseledande eller hot om våld. Dessa rättskränkningar - allvarliga kränkningar av den sexuella självbestämmanderätten, friheten och den kroppsliga integriteten undersöks inte heller skilt som andra brott riktade mot individen, såsom utpressning. Koppleribrottet anses omfatta dessa rättskränkningar. Med tanke på förverkligandet av offrets rättsskydd är detta problematiskt, eftersom föremålen för koppleri enligt rådande praxis nästan alltid har enbart ställning som vittne, inte målsägande, i straffprocessen. Ur förundersökningsmyndigheternas synvinkel är det däremot inte betydelsefullt huruvida gärningen undersöks som koppleri eller människohandel, eftersom straffskalorna och möjligheterna för bruk av tvångsmedel i praktiken sammanfaller vid koppleri och människohandel. Såsom senare kommer att klargöras i artikeln, har den straffprocessuella ställningen en stor betydelse för förverkligandet av offrets rättigheter. 


\subsection{Koppleri som människohandel}

Enheten för rättsligt samarbete inom Europeiska unionen, Eurojust, har i sin omfattande utredning noterat att brottslig verksamhet med drag av människohandel ofta undersöks som något annat brott än människohandel. ${ }^{18}$ En av de största orsakerna för detta anses vara att människohandelsdefinitionen är komplicerad och att de centrala aktörerna inom straffrättssystemet inte har en klar uppfattning om vad som egentligen avses med människohandel. ${ }^{19}$ Framför allt rekvisitet om offrets utsatta belägenhet upplevs som svårtillämpat. Även i Finland har den rättsliga kvalificeringen av människohandel och särskiljandet av människohandel från till exempel koppleri visat sig vara svårare än väntat.

Rekvisiten för människohandel och koppleri är delvis överlappande, vilket även medges i regeringens proposition angående straffbestämmelserna om människohandel. I förarbetena strävas till att särskilja människohandel från koppleri genom att konstatera att gärningsföremålet vid människohandel är mer beroende av en annan persons kontroll än vid koppleri. Ytterligare sägs att i situationer där bägge brottsbeskrivningarna uppfylls skall bestämmelsen om människohandel anses primär i förhållande till bestämmelsen om koppleri, och att avsikten är att tillämpningsområdet för koppleri skall inskränkas efter föreskrivandet om människohandelsparagraferna. I förarbetena konstateras att koppleri även kan bli människohandel om man genom att använda de medel som anges i bestämmelsen om människohandel förmår en prostituerad att fortsätta sin verksamhet. ${ }^{20} \mathrm{I}$ lagutskottets betänkande om saken tilläggs att den som utsätts för människohandel är kuvad på ett mer intensivt och mer övergripande sätt än vid koppleri, och att de ospecifika begreppen »beroende ställning« och »skyddslöst läge« bör tolkas snävt. ${ }^{21}$

Utgående från granskningen av rättspraxis (dvs. rättspraxis gällande människohandel och koppleri) och myndighetsverksamhet verkar det som om strafföreskrifterna om människohandel, utöver det tidigare rättsläget, tillsvidare inte förmått skydda personer som blivit föremål för våld och andra rättskränkningar inom prostitutionen. Genom den verksamhet mot människohandel som grundar sig på internationella förpliktelser strävar man till att förbättra ställningen för personer i utsatt belägenhet och främja förverkligandet av deras rättigheter, såsom rätten till frihet, kroppslig integritet och sexuell självbestämmanderätt. I finsk rättspraxis och myndighetsverksamhet utgår man vid tillämpningen fortfarande från att begränsningar av prostituerades rättigheter, våldshot eller förbindande till skuldförhållanden är »regler« som hänför sig till koppleri, som de prostituerade har gett sitt medgivande till genom att »frivilligt« anlända till Finland och ge sig in i prostitution. Identifieringen av psykologiska kontrollmedel är utmanande. 
Omständigheterna inom koppleriverksamheten eller de prostituerades beroendeställning, sårbarhet eller faktiska möjligheter att skydda sig mot utnyttjande eller lösgöra sig från prostitutionen granskas sällan. Följaktligen igenkänns inte heller potentiella människohandelsoffer eller andra rättskränkningar eller våldshandlingar som riktas mot prostituerade. Problemet utgörs uttryckligen av att människohandel inte igenkänns vid kopplerimål. Enbart ärenden innehållande extremt utnyttjande undersöks överlag som människohandel.

Tillämpningen och tolkningen av definitionen på människohandel kan underlättas genom att spjälka upp människohandelsprocessen i delar. Människohandelsbrottet kan tänkas bestå av tre sammanhängande faser: 1) rekryteringsfasen, 2) transport- och förflyttningsfasen och 3) utnyttjandefasen. Vid rekryteringsfasen är det fråga om offrets värvande och lockande till exempelvis prostitution. Vid transportfasen förflyttas personen från sin egen livsmiljö till omständigheter, där utnyttjandet tar plats. Transporten kan ske antingen inom landet eller så kan den utgöra verksamhet som överskrider de internationella gränserna. Vid utnyttjandefasen försätts personen i en position där denne blir offer för utnyttjande och utnyttjas exempelvis sexuellt i ett ekonomiskt förtjänstsyfte.

Ofta föreställer man sig att människohandel uttryckligen hänger samman med rekryterings- eller transportfasen. Härvid riktas uppmärksamheten mot huruvida offret ursprungligen frivilligt gav sig iväg med människohandlarna, huruvida offret kände till syftet med resan och huruvida offret aktivt motsatte sig prostitueringen före det egentliga utnyttjandet påbörjades. ${ }^{22}$ Detta motsvarar den stereotypiska offerbilden, enligt vilken det vid människohandel vanligen är fråga om verksamhet arrangerad av ansiktslösa organiserade kriminella sammanslutningar, där offrets frihet har berövats genom fysiskt våld eller där offret åtminstone har vilseletts angående arbetets natur och därigenom förmåtts ge sig iväg med människohandlarna. Enligt forskarna har en stor del av människohandelsoffren som utnyttjats sexuellt dock ursprungligen samtyckt till att ge sig in i prostitutionen; en del av dem har redan tidigare fungerat som prostituerade och en del fortsätter inom prostitutionen även efter straffprocessen. ${ }^{23}$

Den internationella definitionen på människohandel ger emellertid skydd även åt människohandelsoffer som ursprungligen samtyckt till prostitutionen: Det kan även vara fråga om människohandel när de medel som nämns i definitionen används först vid utnyttjandefasen. Detta uttrycks genom de i definitionen nämnda gärningssätten: tagande av kontroll (en säregenhet i Finlands strafflag), hysande (i finska strafflagen inhysande) och mottagande. Vid verksamhet som börjat som prostitution eller koppleri kan det således bli fråga om människohandel om gär- 
ningsmannen exempelvis utnyttjar sin maktposition (offrets beroende ställning) eller offrets utsatta belägenhet (skyddslösa läge) vid utnyttjandefasen.

$\AA$ andra sidan gäller tillämpnings- och tolkningsproblemen vid definitionen och de därpå baserade straffbestämmelserna medlen som används vid människohandel. Det allra mest mångtydiga av medlen är utnyttjandet av offrets beroende ställning (maktmissbruk) eller skyddslösa läge (utsatt belägenhet). Dessa medel syftar till obalansen i maktpositionen mellan gärningsmannen och offret och missbruket av offrets utsatthet. Intagandet av dessa medel i definitionen och straffbestämmelserna gällande människohandel utvidgar definitionens tillämpningsområde och inskränker området för s.k. frivillig prostitution. På samma gång stärker dessa medel människohandelsoffrens rättsskydd.

Intagandet av medlen i definitionen är viktigt, eftersom internationell erfarenhet visar att gärningsmännen oftare tyr sig till psykiska påtryckningsmedel än direkt fysiskt våld för att få sitt offer att underkasta sig utnyttjandet. ${ }^{24}$ Rädsla eller oro för anhöriga, misstanke gentemot myndigheter, illegalt uppehåll i landet, beslagtagande av resedokument, tvång orsakat av religiösa riter (t.ex. voudou), skulder, drogberoende, brist på stödnätverk och språkkunskaper, ung ålder, allvarliga psykiska trauman, skam eller andra brister på alternativ som offret av andra orsaker upplever eller försvarslöshet kan på ett lika effektivt sätt som fysiskt våld eller hot om sådant våld förhindra att offret förmår frigöra sig från prostitutionen. Även tidigare sexuellt utnyttjande och ett nära förhållande till gärningsmannen ökar offrets beroende och benägenhet att bli utsatt för utnyttjande (förtroendeförhållande). Vid människohandel förekommer mycket viktimiseringsdynamik som hänför sig till våld i nära relationer. Gärningsmannen tar efterhand och över en längre tid offret i sin makt, varvid offret underkastar sig dålig behandling och utnyttjande.

I denna artikel förespråkas en syn, enligt vilken människohandel inte utgörs av tillfälligt köpslående, utan är en process av utnyttjande och underkastande, där gärningsmannen småningom berövar offrets självbestämmanderätt, kroppsliga integritet och frihet genom att förödmjuka, underkasta, vanhedra och manipulera denne. En osäker och från det övriga samhället isolerad miljö, en känsla av värdelöshet som uppstår till följd av rädsla och annat utnyttjande underlättar kontrollen av offret och leder småningom till att offrets skyddsmekanismer förstörs. Offren kan uppleva sig vara såpass bundna vid gärningsmannen och situationen, att de ser självmord som den enda utvägen och räddningen. Vid tillämpningen och tolkningen av definitionen på människohandel bör uppmärksamhet fästas vid de faktiska mögligheter som offret har för att skydda sig mot våld och utnyttjande samt prostitutionens omständigheter, såsom skäligheten i de regler som hallickar- 
na uppställer, skuldsättande, mängden sexköpare och den ersättningsmängd/andel som offret själv får genom prostitutionen.

\section{Människohandelsoffrens rättigheter}

En korrekt identifiering av människohandel är avgörande med tanke på förverkligandet av offrens rättigheter. Om människohandelsoffren inte identifieras, kan deras lagenliga rätt till hjälp och skydd inte förverkligas. Oidentifierade människohandelsoffer vägleds nödvändigtvis inte till hjälpsystem som grundats i syfte att bistå människohandelsoffer och får inte heller ta del av sina andra rättigheter, såsom möjligheten att söka uppehållstillstånd på basis av viktimisering vid människohandel. Oidentifiering kan leda till att människohandelsoffret avlägsnas ur landet, att utnyttjandet fortsätter och ny viktimisering. För människohandelsoffer som utnyttjats sexuellt är identifieringen ännu viktigare än för personer som är offer för arbetsrelaterad människohandel. Detta beror på skillnaden i straffprocessuell ställning.

I Finland har brottsobjekten för koppleri i första hand ställning som vittne i straffprocessen, men människohandelsoffren har ställning som målsägande. Målsäganden vid människohandelsbrott har till följd av denna straffprocessuella ställning rätt att fă bl.a. ett rättsbiträde och en stödperson med stöd av bestämmelserna i lagen om rättegång i brottmål. Målsäganden har även möjlighet att överklaga en lägre domstols beslut till en högre domstol. Personer som utsatts för arbetsrelaterat utnyttjande har oberoende av brottsrubriceringen alltid ställning som målsägande i straffprocessen (människohandel eller ockerliknande diskriminering i arbetslivet), men föremål för koppleri har i regel enbart ställning som vittnen. Skillnaden i straffprocessuell ställning kan även påverka fastställandet av brottsbaserat skadestånd samt vägledandet av människohandelsoffren till hjälpsystem.

Internationella akter, FN:s tilläggsprotokoll mot människohandel och Europarådets konvention om bekämpande av människohandel som godkändes år 2005, förpliktar avtalsstaterna att tillerkänna människohandelsoffren en särställning, som omfattar bland annat rätten att under vissa förutsättningar bli kvar i landet som människohandelsoffer samt att erhålla social-, hälso- och rättstjänster. Även i Finland har godkännandet av internationella förpliktelser lett till att människohandelsoffer har möjlighet att få bistånd av hjälpsystemet för människohandelsoffer. Enligt lagen om främjande av integration kan tjänster och andra stödåtgärder ordnas för en person som i egenskap av människohandelsoffer har betänketid eller uppehållstillstånd (se närmare nedan) eller som eljest på basis av omständigheterna kan bedömas utgöra ett människohandelsoffer eller vara i behov 
av särskild hjälp vid undersökningen av människohandelsbrott. Tillämpningen av bestämmelserna upphör då grunder för hjälpande inte längre finns.

Syftet med hjälpen är att se till människohandelsoffren och deras uppehälle, främja deras återhämtning samt stöda deras funktionsförmåga. Genom hjälpsystemet för människohandelsoffer får offren individuellt skräddarsydd service. Biståendet av människohandelsoffer kan bestå av bland annat boendearrangemang, social- och hälsotjänster, juridisk rådgivning och hjälp, säkerhetsarrangemang, stöd för hemresa och andra stödåtgärder som offret behöver. Vid biståendet av minderåriga människohandelsoffer och offrens barn kan även barnskyddslagen bli tillämplig. Biståndet är inriktat på offrens återhämtning, integrering eller säkra hemresa. Tjänster eller andra stödåtgärder kan inte erbjudas utan offrens samtycke.

Grundandet av hjälpsystemet har förbättrat människohandelsoffrens ställning. Hittills har drygt hundra människohandelsoffer och offer för närliggande brott till människohandel vägletts till hjälpsystemet. Av dem har ett tjugotal varit minderåriga. Hjälpsystemet har förmått ge bistånd åt åtskilliga offer för människohandel och närliggande brott till människohandel, såsom ockerliknande diskriminering i arbetslivet. Även ett flertal personer som sökt skydd i Finland och som tidigare fallit offer för människohandel i andra EU-medlemsländer har styrts till hjälpsystemet. En del av offren har beviljats uppehållstillstånd och stannat i Finland, en del har återvänt till sitt hemland.

Trots betydande framgångar finns det fortfarande rum för utveckling inom hjälpsystemet. Minoritetsombudsmannen, som fungerar som nationell människohandelsrapportör, har bland annat fäst uppmärksamhet vid att potentiella människohandelsoffer som utnyttjats inom prostitutionen för närvarande inte verkar vägledas till hjälpsystemet för människohandelsoffer, trots att myndigheterna får kännedom om kopplerifall med tydliga drag av människohandel (Minoritetsombudsmannen 2010). Merparten av personerna som hittills vägletts till hjälpsystemet har varit offer för arbetsrelaterat utnyttjande, och blivit utnyttjade inom exempelvis restaurang-, städ- och växthusarbete. En förklaring för detta kan vara att prostituerade som varit föremål för koppleri inte har ställning som målsägande i straffprocessen, varmed deras viktimisering inte uppfattas ens då de prostituerade blivit utsatta för även allvarliga rättskränkningar och till och med människohandel.

Människohandel är ett könsrelaterat fenomen. De människohandelsoffer som identifierats i Europa har fallit offer för sexuellt utnyttjande inom prostitution eller annan sexindustri- och underhållning. Största delen av även de prostituerade, och framför allt de prostituerade som varit föremål för koppleri, är kvinnor. Det 
är motiverat att hävda, att den finska verksamheten mot människohandel har diskriminerande verkningar på basis av offrens kön. Europarådets konvention om bekämpande av människohandel innehåller ett förbud mot diskriminering vid verksamhet mot människohandel. Detta förbud innebär en skyldighet att tillförsäkra att avtalsparterna verkställer konventionens bestämmelser, framför allt åtgärderna som syftar till skydd av delaktiga offer och främjande av deras rättigheter, utan att diskriminera någon på grund av bland annat deras kön. I den förklarande rapporten till konventionen specificeras att konventionens bestämmelser om bistånd av människohandelsoffer och rätten till uppehållstillstånd skall verkställas utan att diskriminera någon på basis av bland annat deras kön (se punkterna 63-69). Konventionen förbjuder även indirekt diskriminering, vilket innebär att verksamheten mot människohandel inte heller får ha diskriminerande verkningar.

Ställningen för människohandelsoffer som vistas illegalt i landet har även förbättrats genom de ändringar som gjorts i utlänningslagen på grund av internationella förpliktelser. ${ }^{25}$ I utlänningslagen har intagits en möjlighet att bevilja människohandelsoffer en betänketid på några månader och ett tillfälligt eller permanent uppehållstillstånd. Betänketiden kan på eget initiativ beviljas av antingen lokalpolisen eller en gränsbevakningsmyndighet, och den kan räcka mellan 30 dygn och sex månader. Under betänketidens gång skall människohandelsoffret besluta om han eller hon kommer att samarbeta med myndigheterna för att de som misstänks för människohandel skall kunna gripas. Under betänketiden utgör uppehållet $\mathrm{i}$ landet lagligt uppehåll, och personen kan inte avvisas från landet under denna tid.

Människohandelsoffer beviljas tillfälligt uppehållstillstånd om människohandelsoffrets vistelse i Finland är motiverad på grund av förundersökning eller domstolsbehandling i anslutning till människohandel, offret för människohandeln är berett att samarbeta med myndigheterna för att de som misstänks för människohandel skall kunna gripas, och offret för människohandeln inte längre har förbindelser med de personer som är misstänkta för människohandel. Människohandelsoffret kan beviljas ett kontinuerligt uppehållstillstånd oberoende av nämnda förutsättningar, om människohandelsoffret befinner sig i en särskilt sårbara ställning. Även i detta fall förutsätts dock att människohandelsoffret har brutit alla förbindelser med de personer som är misstänkta för människohandel. Hittills har både betänketider och offertillstånd beviljats i liten mängd, och då huvudsakligen åt offer för arbetsrelaterad människohandel. Vissa människohandelsoffer har beviljats uppehållstillstånd av individuella humanitära skäl.

Förverkligandet av människohandelsoffrens rättigheter övervakas av minoritetsombudsmannen, som påbörjade sin verksamhet som nationell människohan- 
delsrapportör år 2009. I egenskap av nationell människohandelsrapportör iakttar minoritetsombudsmannen människohandeln och därtill sammanhängande fenomen, övervakar och främjar verksamheten mot människohandel samt rapporterar regelbundet åt riksdagen och statsrådet om sina iakttagelser. Minoritetsombudsmannen kan även biträda ett potentiellt människohandelsoffer vid förverkligandet av dennes rättigheter eller vid behov skaffa rättshjälp åt denne. Minoritetsombudsmannen är en självständig och oavhängig myndighet. I egenskap av nationell människohandelsrapportör har minoritetsombudsmannen omfattande informationsinförskaffningsrättigheter, som med vissa begränsningar utsträcker sig även till medborgarorganisationer som tillhandahåller tjänster.

I flera internationella akter, såsom Europarådets konvention om bekämpande av människohandel (art. 29), rekommenderas utnämnandet av en oavhängig rapportör och övervakare av verksamheten mot människohandel. Antagandet är att grundandet av en sådan här rapporterings- och övervakningsmekanism kommer att främja verksamheten mot människohandel och förverkligandet av offrens rättigheter. Ett motsvarande självständigt och oavhängigt mandat finns utöver Finland enbart i Nederländerna, där den nationella människohandelsrapportören redan har fungerat under tio års tid. ${ }^{26}$

\section{Reflexioner kring identifieringen av sexuellt utnyttjade människohandelsoffer}

Vad gäller problemen att identifiera människohandel kan svar sökas från flera olika håll. För det första står det klart att människohandel utgör dold brottslighet. Ofta strävar inte enbart gärningsmännen, utan även offren, till att gömma sig från myndigheterna. Offren kan frukta hämndaktioner från brottslingarnas sida och förhålla sig skeptiskt till myndigheter. Tröskeln att söka hjälp är hög, eftersom offren inte känner till sina rättigheter. Ofta beskyller offren sig själva för det skedda. Även våldshot som gärningsmännen riktar mot sina offer och deras anhöriga hindrar offren från att ta kontakt med myndigheter. Ibland har offren själva tagit del i den brottsliga eller samhälleligt oönskade verksamheten, såsom prostitution, och de är rädda för att bli straffade och avlägsnade ur landet. Även i Finland utgör en misstanke om säljande av sexuella tjänster en avvisningsgrund enligt utlänningslagen (148 $\S$ i utlänningslagen). Denna bestämmelse kan utsätta sexuellt utnyttjade människohandelsoffer för avlägsnande ur landet. De fall som kommit myndigheterna till kännedom och identifierats som människohandel utgör sannolikt enbart en liten del av hela människohandelsfenomenet.

Ofta förklaras det ringa antalet identifierade människohandelsoffer just genom att hänvisa till människohandelns karaktär som dold brottslighet. Den ovan 
nämnda rapporten av den nationella människohandelsrapportören avslöjar dock att myndigheterna ofta inte känner igen människohandel även då de undersöker människohandelsbrott och har att göra med brottsoffren. Svårigheten att identifiera människohandel kan förklaras av straffbestämmelsernas tillämpning och tolkning, som förstärker en tämligen snäv och idealisk offerbild: För att det skall vara fråga om människohandel måste gärningsmannen ha tvingat offret till prostitution genom bruk av allvarligt fysiskt våld eller genom att vilseleda denne angående arbetets natur. Offret måste åtminstone ha varit utvecklingsstört och därmed försvarslöst. ${ }^{27}$ Människohandelsoffer kan sålunda inte utgöras av personer som ursprungligen samtyckt till att ge sig in i prostitution, trots att omständigheterna för prostitutionen vore mycket dåliga. En dylik tillämpning och tolkning av definitionen på människohandel motsvarar inte den internationella människohandelsdefinitionen.

Delvis kan det låga antalet människohandelsoffer som utsatts för sexuellt utnyttjande förklaras av oförmögenheten att överlag identifiera våld som riktas mot kvinnor. Våld riktat mot kvinnor, vilket även människohandel och tvångsprostitution definieras som i internationella samband, erkändes i Finland utgöra ett samhälleligt problem till stora delar just till följd av den internationella utvecklingen. Kommittén (CEDAW-kommittén) som övervakar FN:s konvention om avskaffande av all slags diskriminering av kvinnor har i sina rapporter angående Finland upprepade gånger fäst uppmärksamhet vid de otillräckliga åtgärderna för att förhindra våld mot kvinnor. ${ }^{28}$

Flera undersökningar visar att våld i nära relationer fortfarande är allmänt $\mathrm{i}$ Finland, och att till exempel våldtäktsoffer i straffprocessen skuldbeläggs för att ha fallit offer för våld, framför allt då offret och gärningsmannen känt varandra före brottet. Forskarna har likväl konstaterat att det råder en felaktig kultur av ansvarsbeläggande av kvinnor i Finland, där kvinnorna själva anses vara ansvariga för våldet: Antingen borde de ha förmått undvika situationer som potentiellt kan leda till våld (såsom situationer av s.k. »date rape « ( $^{29}$ eller aktivt söka sig bort från våldsamma situationer (som situationer av våld i nära relationer). ${ }^{30} \mathrm{I}$ Finland har man i huvudsak strävat till att främja jämställdheten mellan kvinnor och män genom jämställdhetspolitiska åtgärder, varvid kriminalpolitiken och straffrätten spelat en begränsad roll vid förbättringen av kvinnornas ställning. Den i konsensusanda bedrivna jämställdhetspolitiken, som strävar till undvikande av motstridigheter könen emellan, har fokuserat på jämställdheten mellan kvinnor och män i framför allt arbetslivet. Kvinnospecifika frågor, såsom våld riktat mot kvinnor, har för sin del fătt betydligt mindre uppmärksamhet. 
Ställningen för kvinnor som är med i prostitution är emellertid ännu mer utmanande än kvinnors ställning i allmänhet. Internationella undersökningar visar att prostituerade är särskilt utsatta för sexuellt och fysiskt våld, ${ }^{31}$ men rättssystem hela världen över har svårigheter att identifiera våldet och reagera på det på ett sätt som tryggar offrens rättigheter. ${ }^{32}$ Även i Finland har det visat sig vara utmanande att identifiera våld inom prostitution. Trots att omständigheterna inom prostitutionen skulle vara dåliga och frigörelsen från prostitutionen skulle hindras genom exempelvis skuldsättning, hotelser och begränsning av rörelsefriheten, tolkas verksamheten inte som människohandel eller någon annan slags kränkning av personens rättigheter, utan som koppleri, om personen ursprungligen samtyckt till att gå med i prostitutionen. Våldshot och andra påtryckningar anses ofta av naturen höra till prostitutionen och koppleriverksamheten, framför allt då det är fråga om en utländsk kvinna.

Den ovan granskade rättspraxisen och myndighetsverksamheten gällande undersökningen av kopplerimål verkar ge uttryck för en uppfattning, enligt vilken personer som valt prostitution har tagit en medveten risk att bli föremål för våld genom att komma till Finland och ge sig in i prostitution. Om riskerna förverkligas, ansvarar de prostituerade själva för de därav beroende följderna. Våldskontexten, och vem som våldet riktar sig mot, definierar sålunda våldets förkastlighet. Kvinnor som själva sökt sig till prostitution och utsatts för våld uppfattas vanligen inte som offer för människohandelsbrott, och ofta inte heller som offer för något annat slags brott, utan man föreställer sig att de själva är ansvariga för att ha fallit offer för våld. Oskuldsfullhet och oskyldighet, passivitet och hjälplöshet är något som förutsätts av ideala människohandelsoffer. Om de har bidragit till sin viktimisering genom att ursprungligen samtycka till att ge sig in i prostitutionen, kan de inte i rättssystemets ögon utgöra trovärdiga människohandelsoffer och kan därför ha svårigheter att söka eller få hjälp och stöd. ${ }^{33}$ Föremålen för koppleribrott har vanligen inte målsägande-, dvs. offerställning, i straffprocessen.

Detta kan vara överraskande i ett land där man vanligen förhåller sig tämligen negativt till prostitution och sexhandel, och där man även har ett partiellt förbud mot sexköp i kraft. Genom det partiella förbudet mot sexköp strävar man till att förstärka den sexuella självbestämmanderätten hos personer som är föremål för kommersiell verksamhet samt minska på efterfrågan av sexhandel och därigenom människohandel och koppleri. Trots lagändringarna tvistar man ännu om förbudet mot sexköp och dess berättigande och funktionalitet.

Även rättshistoriska orsaker kan erbjuda en förklaring till varför människohandel som hänför sig till sexuellt utnyttjande och annat våld inom prostitutionen inte identifieras. Den finska lagstiftningen har nästan alltid strävat till att kontrol- 
lera prostitutionen på grund av de hälsorisker och säkerhetshot som anknyter till den. Den s.k. reglementerade prostitution som togs i bruk medlet av 1800-talet tvingade de prostituerade att registrera sig och delta i regelbundna hälsogranskningar. Härigenom ville man förhindra spridningen av bland annat syfilis. Reglementeringen upphörde officiellt år 1908, men i praktiken först år 1942. Efter krigen strävade man till att kontrollera prostitutionen genom lagen om lösdriveri. Föreställningen var att lösdriveri och prostitution hängde samman med brottslighet och oordning. Lagen om lösdriveri möjliggjorde att de prostituerade kunde föreläggas underlydnad av lösdriveriövervakning, läkargranskningar och tvångsarbete. Lagen om lösdriveri upphävdes i slutet av 1980-talet. ${ }^{34}$

Prostitutionen blev igen föremål för samhällelig diskussion under 1990-talet, då antalet prostituerade utlänningar ökade i Finland. Prostitutionen blev i accentuerad mån en utlännings- och säkerhetsfråga. Man strävade härvid till att kontrollera prostitutionen genom att straffbelägga köpande och erbjudande av sexuella tjänster på allmänna platser (ordningslagen) samt föreskriva en särskild paragraf i utlänningslagen, som gjorde det enklare att avlägsna utländska prostituerade ur landet. Mot denna historiska bakgrund är det förståeligt att identifieringen av människohandel som hänför sig till sexuellt utnyttjande, eller för den delen andra brott mot person, är utmanande.

\section{Till slut}

Identifieringen av arbetsrelaterad människohandel ses i flera europeiska länder som en av de största utmaningarna för verksamheten mot människohandel. I Finland igenkänns dock människohandel som hänför sig till prostitution och sexuellt utnyttjande betydligt mer sällan än arbetsrelaterad människohandel och därtill anknutet utnyttjande av arbetskraft. Våld och andra rättskränkningar inom prostitutionen igenkänns överhuvudtaget dåligt. I denna artikel har reflekterats över varför sexuellt utnyttjade människohandelsoffer i Finland identifieras exceptionellt sällan i en internationell jämförelse. ${ }^{35}$

Svar på denna fråga har sökts i mångtydigheten och den praktiska tillämpligheten av människohandelsdefinitionen i internationell rätt samt definitionens strikta tolkning i rätts- och myndighetspraxis. Svar har även sökts i rättshistoria och den kontextbundenhet som anknyter till förkastligheten av våld. Konstellationen påverkas även av det konsensusorienterade jämställdhetstänkande som råder i Finland. Så länge detta tänkande råder är det svårt att överlag identifiera våld som riktas mot kvinnor.

Lagstiftning som grundar sig på internationella förpliktelser ger människohandelsoffren en särposition och därav följande rättigheter. Även människohan- 
delsoffer som vistas illegalt $i$ landet måste få hjälp och under vissa förutsättningar måste deras uppehåll i landet tillåtas genom lag. Verksamheten mot människohandel har möjligheten att synliggöra våldet inom prostitutionen och förbättra de prostituerades rättsskydd. Hittills har verksamheten mot människohandel inte förmått göra detta: Människohandelsoffrens rättigheter förverkligas inte, eftersom våld och utnyttjande inom prostitutionen fortfarande inte känns igen. Identifiering är en förutsättning för förverkligandet av människohandelsoffrens rättigheter, vilket ett av syftena med denna artikel har varit att förevisa. Identifiering är särskilt betydelsefullt för sexuellt utnyttjade människohandelsoffer.

Europeiska människorättsdomstolens fall Rantsev mot Cypern och Ryssland (2010) stärker människohandelsoffrens rättssäkerhet även i Finland. Fallet handlade om en rysk flicka som reste till Cypern med ett s.k. artistvisum. Där blev hon offer för sexuellt utnyttjande och hittades slutligen död under sin balkong. Människorättsdomstolen kom i sin dom fram till att både avfärdslandet Ryssland och destinationslandet Cypern hade brutit mot människorättskonventionen. Domstolen ansåg att Ryssland hade kränkt artikel 4 i människorättskonventionen, eftersom människohandelsbrottet inte hade undersökts. Cypern hade kränkt bl.a. artikel 2 och 4, eftersom orsakerna som föranlett offrets död inte hade undersökts, och tillräckligt effektiva åtgärder för att skydda offret inte hade vidtagits. Domstolen ansåg att avtalsstaterna har en skyldighet att förhindra människohandel genom till exempel vederbörliga utlänningslagar, bistående och skyddande av människohandelsoffer samt att undersöka människohandelsbrott och i det ifrågavarande fallet de omständigheter som lett fram till offrets död.

För att Finland skall kunna uppfylla sina på internationella konventioner baserade förpliktelser att förhindra människohandel, bistå och skydda människohandelsoffer och undersöka människohandelsbrott, måste hjälpsystemet för människohandelsoffer förbättras, arbetet för efterspårandet av offer utvecklas och strafflagen ändras så att människohandelsoffer lättare kan identifieras. Detta innebär att strafflagens bestämmelser om människohandel och deras förhållande till koppleriparagraferna måste förtydligas. Verksamheten mot människohandel borde även ur en könssynvinkel utvecklas så, att samtliga människohandelsoffer på ett tillbörligt sätt skulle identifieras och bistås, oberoende av om de fallit offer för sexuellt eller arbetsrelaterat utnyttjande. Sexuellt utnyttjade människohandelsoffers ställning borde förbättras exempelvis därigenom, att även personer som är föremål för (grovt) koppleri på ett mera systematiskt sätt än nu skulle vägledas till hjälpsystemet och att sådana personer i större mån än tidigare skulle beviljas målsägandeställning i straffprocessen. 


\section{Noter}

1. Venla Roth arbetar som sakkunnig i ärenden med anknytning till människohandel vid minoritetsombudsmannens / den nationella människohandelsrapportörens byrå. Roth disputerade för juris doktorsgraden i januari 2010 med en avhandling som behandlade verksamheten mot människohandel och dess inverkan på de mänskliga rättigheterna.

2. United Nations Office on Drugs and Crime (UNODC): Global Report on Trafficking in Persons. Wien: United Nations Office on Drugs and Crime, 2009.

3. Coster van Voorhout, Jill E. B.: »Human trafficking for labour exploitation: Interpreting the crime«. Utrecht Law Review, Vol. 3, No. 2 (2007), 44-69.

4. United Nations Office on Drugs and Crime (UNODC): Trafficking in Persons: Global Patterns. Wien: United Nations Office on Drugs and Crime, 2006.

5. International Labour Organisation (ILO): A Global Alliance Against Forced Labour. Global Report under the Follow-up to the ILO Declaration on Fundamental Principles and Rights at Work 2005. International Labour Conference, 93rd Session 2005, Report I (B). Geneve: International Labour Office, 2005.

6. Utrikesministeriet: Ihmiskaupan vastainen toimintasumnitelma. Helsinki: Ulkoasiainministeriö, 2005.

7. Se League of Nations: Report of the Special Body of Experts on Traffic in Women and Children. Part One. Wien: League of Nations, 1927 och Walcowitz, Judith R.: Prostitution and Victorian Society. Women, Class, and the State. Cambridge: Cambridge University Press, 1980.

8. Se även tilläggsprotokollet mot smuggling av migranter land-, luft- och sjövägen, som även det utgör ett tillägg till FN:s konvention mot gränsöverskridande organiserad brottslighet (FördrS 73/2006).

9. Gallagher, Anne: Human trafficking: international law and international responsibility. A critical examination of the international legal response to human trafficking with a particular focus on the state responsibility regime as a means of securing greater accountability of governments for trafficking and related exploitation. Utrecht: Utrecht universitet, 2006 (opublicerad avhandling).

10. Agustin, Laura: »Daring Border-Crossers: A different vision of migrant women«. I verket Sex Work, Mobility and Health in Europe, Helen Ward och Sophie Day, 85-94. London: Kegan Paul, 2004; Balos, Beverly: »The wrong Way to Equality: Privileging Consent in the Trafficking of Women for Sexual Exploitation«. Harvard Women's Law Journal, Vol. 27, No. 1 (2004), 137-175; Barry, Kathleen: Female Sexual Slavery. New York: New York University Press, 1984; Doezema, Jo: »Ouch! Western feminists’ »wounded attachment« to the "third world prostitute««. Feminist Review, Vol. 67, No. 1 (2001), 16-38; Farley, Melissa: »»Bad for the Body, Bad for the Heart«: Prostitution Harms Women Even if Legalised or Decriminalised«. Violence Against Women, Vol. 10, No. 10 (2004), 1087-1125; MacKinnon, Catherine: »Prostitution and Civil Rights«. Michigan Journal of Gender \& Law, Vol. 1, (1993). 13-31; Pheterson, Gail. »Part One: Not Repeating History«. I verket $A$ Vindication of the Rights of Whores, Gail Pheterson, 3-30. Seattle: Seal Press, 1989.

11. Report of the Ad Hoc Committee on the Elaboration of a Convention against Transnational Organized Crime on the work of its first to eleventh sessions: Addendum. Interpretative notes for the official records (travaux préparatoires) of the negotiation of the United Na- 
tions Convention against Transnational Organized Crime and the Protocols thereto, A/55/383/Add. 1

12. Konventionens verkställighet övervakas av sakkunnigorganet GRETA (Group of Experts on action against trafficking in human beings). Finland har undertecknat konventionen i augusti 2006, men har ännu inte ratificerat den.

13. Lehti, Martti, och Aromaa, Kauko: Naiskauppa, laiton siirtolaisuus ja Suomi. Nykytilanne, lainsäädäntö ja tutkimuslähteet. Helsinki: Oikeuspoliittinen tutkimuslaitos, 2002 och Leskinen, Jari: »Organisoitu paritus ja prostituutio Suomessa«. I verket Rikostutkimus, 9-30. Vantaa: Keskusrikospoliisi, 2002.

14. Leskinen, Jari: »Organisoitu paritus ja prostituutio Suomessa«, 10-13. I verket Rikostutkimus, 9-30. Vantaa: Keskusrikospoliisi, 2002.

15. Kimpimäki, Minna: Neljä artikkelia ihmisestä kaupan kohteena: A: Varsinainen ihmiskauppa, B: Lapsikauppa, C: Elinten, kudoksien ja sukusolujen kauppa, D: Kaupallinen erotiikka. Rovaniemi: Lapin yliopisto, 1997; ochPärssinen, Venla (nimera Roth): Ihmiskauppa rikoksena Suomen lainsäädäntömaisemassa: Ehdotus hallituksen esitykseksi rikoslain 25 luvun ja oikeudenkäynnistä rikosasioissa annetun lain muuttamisesta. Turku: Åbo universitet, 2003.

16. Förändringen i attityden påverkades även av den i USA år 2003 publicerade välkända rapporten »Trafficking in Persons«, enligt vilken Finlands åtgärder mot människohandel var ineffektiva.

17. Minoritetsombudsmannen/Den nationella människohandelsrapportören: Berättelse 2010 . Människohandel och relaterade fenomen samt tillgodoseendet av offrens rättigheter i Finland. Helsinki: Vähemmistövaltuutettu, 2010.

18. De Jonge, Boudewijn: Eurojust and Human Trafficking. The State of Affairs. Haag: Eurojust och Amsterdams universitet, 2005.

19. Danziger, Richard: »Where are the victims of trafficking? « Forced Migration Review, Vol. 25, No. 2 (2006), 10-12.

20. RP 34/2004 rd.

21. LaUB 4/2004 rd.

22. Se ytterligare t.ex. Doezema, Jo: »Forced to Choose: Beyond the Voluntary v. Forced Prostitution Debate«. I verket Global Sex Workers: Rights, Resistance, and Redefinition, Kamala Kempadoo och Jo Doezema, 34-50. New York: Routledge, 1998; ochDoezema, Jo: »Who gets to choose? Coercion, consent and the UN Trafficking Protocol«. Gender and Development, Vol. 10, No. 1 (2002), 20-27.

23. Kligman, Gail, och Limoncelli, Stephanie: »Trafficking Women after Socialism: To, Through, and From Eastern Europe«. Social Politics: International Studies in Gender, State \& Society, Vol. 12, No. 1 (2005), 118-140; Skilbrei, May-Len, och Tveit, Marianne: »Defining Trafficking Trough Empirical Work. Blurred Boundaries and their Consequences«. Gender, Technology and Development, Vol. 12, No. 1 (2005), 9-30; Vocks, Judith och Nijboer, Jan: »The Promised Land: A Study of Trafficking in Women from Central and Eastern Europe to the Netherlands«. European Journal on Criminal Policy and Research, Vol. 8, No. 3 (2000), 379-388.

24. Surtees, Rebecca: Second Annual Report on Victims of Trafficking in South-Eastern Europe. Geneve: IOM, 2005. 
25. Framför allt direktivet (2003/81/EG) om betänketid och uppehållstillstånd för människohandelsoffer som godkändes i Europeiska unionen år 2004.

26. Dutch National Rapporteur: Trafficking in human Beings. Ten years of independent monitoring. Haag: BNRM, 2010.

27. Se närmare även Roth, Venla: »Paritusta vai ihmiskauppaa?« Defensor Legis, No. 3 (2007), 436-437 och Roth, Venla: Defining Human Trafficking, Identifying Its Victims: A Study on the Impact and Future Challenges of the International, European and Finnish Legal Responses to Prostitution-Related Trafficking in Human Beings. Turku, 2010.

28. Concluding Comments of the Committee on the Elimination of Discrimination Against Women: Finland, UN Docs. A/44/38 och A/50/38; Consideration of Reports of States Parties: $3^{\text {rd }}$ and $4^{\text {th }}$ periodic reports: Finland, UN Doc. CEDAW/C/2001/I/CRP.3/Add.1.

29. Kainulainen, Heini: Raiskattu? Tutkimus raiskausten käsittelemisestä rikosprosessissa. Helsinki: Oikeuspoliittinen tutkimuslaitos, 2004; och Kainulainen, Heini: »Raiskausten käsitteleminen rikosprosessissa uhrin näkökulmasta«. I verket Väkivalta: Seuraamukset ja haavoittuvuus. Terttu Utriaisen juhlakirja, Mirva Lohiniva-Kerkelä, 79-94. Helsinki: Talentum, 2006.

30. Ruuskanen, Minna: Hätävarjelu ja parisuhdeväkivalta. Helsinki: Suomalainen Lakimiesyhdistys, 2005; Ruuskanen, Minna: »The »Good Battered Woman«: A Silenced Defendant.«I verket Responsible Selves. Women in the Nordic legal culture, Kevät Nousiainen, Åsa Gunnarsson, Karin Lundström och Johanna Niemi-Kiesiläinen, 311-329. Aldershot: Ashgate, 2001.

31. O'Connell Davidson, Julia: Prostitution, Power and Freedom. Cambridge: Polity Press, 1998.

32. Sullivan, Barbara: »Prostitution and Consent: Beyond the Liberal Dichotomy of »Free or Forced««. I verket Making Sense of Sexual Consent, Mark Cowling and Paul Reynolds, 127-139. Aldershot: Ashgate, 2004.

33. Se närmare t.ex. Honkatukia, Päivi: Uhrit rikosprosessissa - haavoittuvuus, palvelut ja kohtelu. Oikeuspoliittisen tutkimuslaitoksen tutkimuksia 252. Helsinki: Oikeuspoliittinen tutkimuslaitos, 2011.

34. Järvinen, Margaretha: Fallna kvinnor och hållna kvinnor: polisen och prostitutionen i Helsingfors åren 1965, 1975 och 1980-1985. Åbo: Åbo Akademi, 1987.

35. United Nations Office on Drugs and Crime (UNODC): Global Report on Trafficking in Persons. Wien: United Nations Office on Drugs and Crime, 2009. 